\title{
Attitudes toward Redistributive Policy: An Introduction
}

\author{
Liza G. Steele ${ }^{1, *(\mathbb{D})}$ and Nate Breznau ${ }^{2}$ (D) \\ 1 John Jay College of Criminal Justice, City University of New York (CUNY), New York, NY 10019, USA \\ 2 Global Dynamics of Social Policy Comparative Research Center, University of Bremen, 28359 Bremen, \\ Germany \\ * Correspondence: lsteele@alumni.princeton.edu
}

Received: 10 June 2019; Accepted: 21 June 2019; Published: 28 June 2019

\begin{abstract}
We provide an overview of the field of preferences for redistribution research, including divergent terminological and theoretical approaches. We review the different uses of public attitudes, policy preferences and public opinion. We outline the theoretical roles of material interests, values and opinion-policy endogeneity. We also introduce and summarize the original research presented in this Special Issue. Among the key contributions of the Special Issue to the subfield are novel explorations of how socialization affects preferences for redistribution; an examination of how perceptions about inequality translate into policy preferences; a call for more research into the links between taxation and social policy preferences; explanations for the paradox of low levels of support for redistribution in the famously-generous Nordic countries; and new insights into class-specific policy preferences as well as the roles of immigration and diversity in determining such preferences.
\end{abstract}

Keywords: attitudes about redistribution; preferences for redistribution; social policy preferences; welfare state attitudes

\section{Introduction to Inequality and Public Preferences}

The concentration of income and wealth among an increasingly smaller share of the global population [1] may threaten the stability of societies and their social security and economic productivity. A dramatic neoliberal turn began in the United States and United Kingdom in the 1980s that meant retrenchment of social insurance and social protection systems [2,3]. Several Western European welfare states followed suit, especially in the new Millennium. In tandem with demographic aging and globally competitive markets, retrenchments of redistributive social, wage, and tax policies could have sweeping negative effects on the welfare and economic security of a majority of people $[4,5]$. Income and wealth inequality are not the only indicators of these growing social problems. Childhood poverty and obesity, crime, health and household debt increased in both intensity and scope for the lower end of the income and wealth hierarchies [6-8]. Thomas Piketty, Occupy Wall Street, G8/G7 protests, and neo-nationalist party rhetoric brought income and wealth inequality into a prominent place in the public and academic spheres $[9,10]$. This prompts our continued attention to inequality and redistribution as scholars of policy preferences. Therefore, we ask: Do the publics across the globe take up positions in opposition to inequality?

As the income distribution stratifies, those at the top gain more and more capital with which to influence media and politics [11,12]. These people are not supportive of redistributive taxes and policies in general because they stand to lose the most in the process of funding such policies. Funding means wage increases that are likely to reduce corporate profits, or social policy spending increases necessitating higher taxes or reduced tax breaks, all else equal. At the same time, those in the lower income strata find it increasingly difficult to successfully compete for scarce resources [13]. 
At a certain point, the masses of individuals affected by inequality should become so discontented and face such high social risks as to become activists against inequality. In societies with efficient democratic institutions, this means voting and activism should bring more redistributive-friendly agendas, politicians, and parties into power. A precursor to these political actions is presumably preferences and public opinion. Without publics in favor of redistribution, it seems unlikely if not impossible that policymakers will increase the degree of redistributive policy. This means that public opinion is an augury of any potential changes away from the steady global march toward inequality. Thus, the study of preferences and public opinion regarding inequality and redistributive policy is of great importance at this historical moment.

Research on attitudes and public opinion has a rich history, in particular since the rise of cross-national comparative surveys. Prior to comparative surveys, scholars had to stitch together disparate questions from the available local surveys to paint any kind of cross-national picture. Although some of this work is impressive [14], it left the main variable of interest susceptible to an incredible amount of unobserved heterogeneity and non-invariance across societies. Even with high-quality surveys, there remains much to learn about measuring policy preferences, understanding the causes of attitudes and preferences, how context matters (institutions and values), and the relationship of social inequality with subjective or normative perceptions of society. This article reviews some of the history of attitudes, preferences, and public opinion regarding inequality and redistribution. Then it introduces our Special Issue of this journal and how its articles contribute to the state of the art in this interdisciplinary field. First, we review key theoretical concepts and some of the findings that constitute the mainstream of redistributive preferences research. In doing so, we identify many areas where further research is of critical importance. Then we discuss each contribution to this Special Issue and how it links to the state of the art in this diverse topic.

\section{Key Theoretical Concepts}

Preferences for redistribution is a topic that manifests in many forms. In particular, studies of 'attitudes' and 'public opinion' are areas of inquiry into redistributive preferences, but they do not always speak to each other as bodies of knowledge. Several theories categorize how redistributive preferences come into being and aim to explain their variation across societies, socioeconomic strata, gender, race or ethnic background. These theories cluster in sometimes disparate realms, with some favoring rationality and median-voter logic, others focusing on values and normative positions, and others interested in psychological factors. The labels attached to the object of inquiry already create confusion because there are so many, and this may be a source of the general lack of coherence.

\subsection{Attitudes, Preferences, and/or Public Opinion}

The most common three concepts related to what individuals and societies think or prefer when it comes to redistributive policy are attitudes, preferences, and public opinion. Each has overlapping components ontologically; however, each carries separate spheres of research that often exist in isolation. The concept of attitude prevails among social psychologists who draw on psychology and sociology research. A key feature of the emergence of social psychology as a field is attention to attitudes [15-17]. Research on communication and persuasion is closely linked to attitude research as well, although many communication researchers focus on discourse in the public sphere and therefore also speak about public opinion [18]. The concept of preferences tends to appear among researchers focused on policy or politics, often sociologists and political scientists [19-21]. As an alternative to public opinion, the terms 'mass preferences' or 'mass beliefs' appear in the literature [22-24]. "Preferences" is the most interchangeable term, often used synonymously or analogously with attitudes, beliefs, and public opinion [25-27]. "Public opinion" is perhaps the most confusing yet most powerful of the three terms.

Public opinion is a singular noun as an opinion but referencing a plurality of something among a public. A 'singular plurality', ergo a seeming oxymoron. Public opinion has many definitions, but most of them align on some key features. Public opinion tends to reference positions, attitudes, preferences 
and the like that are widely held or widely acknowledged [28]. Thus, it links to the concept of the public sphere where issues of public interest-like abortion or gay marriage-appear regularly, and others are aware of the discussions surrounding them [29,30]. Public opinion does not exist in any one person but exists at the societal level, in the networks or communications between individuals in that society. It carries with it a theory that it acts as a force; that public opinion influences policy, social movements, and the history of societies [31-33]. Understood as a dialectic process, public opinion and the individuals among the public are both influencers of and influenced by public opinion.

Those who research "policy preferences" implicitly place value on this topic, and this value logically derives from the idea that preferences somehow matter for society and politics. This makes them perhaps dangerously close to the concept of public opinion. But the usage of the term preferences is far less controversial and contains less previous theorizing than the term public opinion. Therefore, the usage of "preferences" or "mass preferences" may be a means of circumventing criticisms that one might otherwise encounter when using the term "public opinion". Awareness of potential confusions relating to these three concepts should be in the minds of researchers aiming to understand attitudes toward inequalities, or what we might also have termed 'public opinion toward inequality' or 'preferences for redistribution' in the title of this Special Issue. Given the vagaries or interchangeability of terms, we did not push authors in any particular direction in terminological usage, but we assert that any scholarship on preferences, attitudes or public opinion should carefully consider the theories, especially stemming from public opinion research, that preferences in the aggregate or on the whole for a given society have an impact on that society. This immediately demands some attention to clearer definitions of the focus of this Special Issue and how it might exist or cause other things to change.

Here we focus on redistributive preferences (also attitudes and opinion). Redistribution takes on different meanings depending on the context or question. For many people, redistribution signals taking from those with more and giving to those with less, a kind of 'Robin Hood' process-in particular, income redistribution. Others think of taxation and spending, especially policymakers who have difficult choices in both budget-making and special interest placation. How to fund redistribution is a recurring question. With aging societies experiencing a plummeting dependency ratio [34], the question of 'who will foot the bill' is of great urgency [35]. Redistributive policies for scholars and perhaps economists specifically might include anything that draws from the common tax pool and then provides transfers or services that are taken up proportionately more by those who contribute less. From this perspective, health policy is redistributive, at least under national or mandatory health insurance models. Most social protection policies providing basic assistance such as food, housing or labor market placement would also be redistributive from a resource transfer perspective. This also depends on the progressivity of taxes. Other forms of policy could be seen as perversely redistributive, taking from the bottom and giving to the middle or top. This is an argument often applied to the United States, which gives massive tax breaks for private middle class spending on what would otherwise be social policy, a phenomenon often labeled the 'hidden welfare state' [2,36]. In summary, 'social policy preferences', 'tax preferences', 'spending preferences', and 'social welfare preferences' are also variants of redistributive preferences.

\subsection{Material Interests}

A common theoretical perspective is to ascribe material self-interest as a cause of policy preferences. This simply means that those higher in the socioeconomic hierarchy are less likely to support redistributive policy because they have more to lose and less to gain from the policy. It is the basis for the median voter theory [37] and its extensions beyond median-income and left-right party positioning as drivers of rational calculations $[38,39]$. This logic fits rational choice theories that unambiguously put physical well-being at the center of preference formation [40]. However, extensions of rational choice theory lead to the inclusion of normative, physiological, and social desirability factors. When extended far enough, rational choice theory risks becoming a tautology, falling out of the middle-range of testable theories [41]. Self-interest logic links to Weber's concept of rationality that applies to material 
interests known as means-ends rationality (Zweckrationalität) [42], i.e., that seeking material well-being dictates policy preferences for or against redistribution.

Quantitative research in the area of material interests relies on median-voter logic and regression to the mean redistributive preference [43-45]. However, in almost all nonmedian-voter quantitative analyses of survey data measuring redistributive preferences, the same structural variables incorporated in testing median-voter theories appear as 'control variables'. There are few studies that do not include income, education, occupation or combinations thereof used to measure socioeconomic status (SES) in models predicting policy preferences. Sadly, perhaps, many of these studies simply throw in these variables without explicitly linking them to preferences in their theoretical discussions. This means that all studies have some kind of implicit material interest logic, but their contribution to knowledge is tenuous without theory.

Most studies that do theoretically tackle structural variables tend to hypothesize different mechanisms or effects across SES levels. Here interactions reveal that variables such as immigration or unemployment may differentially influence low and high SES individuals in their policy preferences [46-48]. Some of these arguments relate to skills rather than income. Those in occupations demanding higher, more specific skills should be more in favor of redistributive social policies to protect them in their potentially longer unemployment spells [49]. The cross-disciplinarity of research also contributes to lack of coherent theories relating to material or self-interest, as many scholars are not aware of studies in other disciplines, especially between economists, who unambiguously stick to the economic literature, and other social sciences.

Material interests also operate on a group level. Sometimes individuals behave contrary to their own material self-interest when they have group resources in mind. This is a key feature of social identity theory and forms a strong area of policy preferences research. Individuals tend to identify with their own 'kind', whether this be genetic, cultural, religious, ethnic, national or in some other way socially constructed [46]. Therefore, individuals seek to protect their own group (the 'ingroup') from material threats from any real or imagined outgroups. In an era of mass migration, this suggests that individuals become chauvinistic, supporting redistribution for their own group while opposing it for other groups [50,51]. However, when chauvinistic policies are not tenable, individuals may oppose redistribution for everyone to prevent any 'freeriding' or material transfers to the outgroup [52-54]. But research is often inconclusive when trying to clearly identify chauvinism, and whether this is based on material interests or simply xenophobia.

\subsection{Values and Political Ideology}

Individual policy preferences do not always align with material self-interest. Theories of values and ideology offer an explanation for this. Values refers to principles of behavior or normatively desirable outcomes. Given that the term "value" seldom occurs in singular form unless referencing the worth of something, "values" is a peculiar plural word to apply to a quality held by any given individual, e.g., 'family values' or 'cultural values'. Values and ideology are synonyms; however, a large literature incorporates ideology in reference to political ideology—an individual's subjective position in the political left-right spectrum. Values therefore arises as a word to characterize nonpolitical beliefs such as egalitarian or justice values. The idea behind both values and ideology is that they are more permanent than attitudes and preferences.

Weber distinguished value rationality (Wertrationalität) as another format to describe individual behaviors such as the adoption of policy preferences. A higher SES person might support higher taxes or more spending on poorer persons out of egalitarian values, but in opposition to that person's material self-interest [55]. Depending on the particular framing of the question or the context, an individual might express different redistributive preferences. Given that media messages are normatively persuasive [56] and that individuals tend to use heuristic cues to quickly express a preference on the spot [57], the role of self-interest or values in shaping preferences likely depends on the context. For example, partisanship, prior positions on a given issue, strength or salience of an issue, media framing 
and strength of individual attitudes related to any given issue might lead to different responses by the same individual to the same polling question [58-61].

The findings on values and ideology are quite consistent. In predictive models, individuals harboring more egalitarian or justice values tend to be more supportive of redistributive social policy, net of the effects of SES variables [55,62-64]. Individuals with more left-leaning political ideologies also express more support of redistributive policies $[65,66]$. Among this research, scholars considering attitudes toward the government such as trust or governmental efficacy find that they moderate or have a large impact on redistributive preferences, suggesting that all operate together as part of the data-generating model $[66,67]$. The caveat to values and ideology research is that attempts to link them to preferences may suffer from endogeneity bias. Conceptually, values and ideology are distinct from policy preferences; however, empirically, these are often measured via questions in the same survey. This risks what some scholars refer to as simply predicting an attitude with an attitude [68].

\subsection{Latent and Endogenous Preferences}

The proto attitude research instrument is the survey. All surveys come with error, be it from sampling or design [69]. As an instrument to measure the complexity of policy preferences, the survey has its shortcomings and unreliability because it attempts to fit " ... idiosyncratic attitudes of respondents into cleanly defined and specific questions in a controlled environment" [70]. Given the complex causal pathways leading to individuals' survey responses, and given a range of other erratic sources of variation, reliance on a single question to measure an individual's attitude or a single-question mean to measure public opinion for the whole of society are the least reliable survey methods [71-74]. Even in simple questions, respondents occasionally fail to accurately report things like their age [75]. At best, policy researchers using survey data have unreliable measurement of policy preferences. Therefore, latent variable measurement techniques provide more reliability in this research area.

Latent as a concept means that preferences are not directly observable-that individuals have preferences and these preferences cause their responses on surveys; however, many other things cause their responses on surveys, and therefore, several questions are necessary to triangulate the underlying preference. Moreover, simply averaging several questions might introduce error because some questions are better at tapping into the underlying attitude than others. Therefore, to operationalize public opinion as latent using structural equation measurement techniques such as factor analysis provides great improvements over single questions or average scales $[73,76]$. Through latent variable measurement techniques, scholars gain insights into what is likely a multidimensionality to redistributive policy preferences $[77,78]$. There is no single redistributive preference but different preferences such as the ideal role of the government in redistribution or social policy making (i.e., should there be policies that redistribute?), the preferred level of redistribution (how much redistribution or how much spending?) or the strength of the attitude (what is an adequate trade off to achieve redistributive policy?), for example.

Among research treating preferences as latent, a key distinction arises in preferences as absolute or relative [79]. For example, individuals may prefer a high level of redistribution, but if they live in a universalistic Nordic welfare state, they might not express demand for more redistribution, whereas if they live in a liberal atmosphere such as the United States or Canada, they might express great demand. In other words, the expressed preference depends on the current level [80-82]. This means that macrocomparative research on preferences tends to view existing institutional arrangements in states as crucial for policy preference formation [83-86].

Latent and institutional perspectives carry simple policy preferences research into an alternative theoretical paradigm. For example, the thermostatic feedback and increasing returns perspectives suggest that preferences not only influence policy, but policy influences preferences [31,87]. Therefore, preferences are not only relative to the current level of policy but in fact part of an endogenous feedback process that determines both preferences and policies, i.e., that there is reciprocal causality between 
them [88-90]. Unfortunately, preference researchers rarely consider this endogeneity problem and instead divide between those treating preferences strictly as a dependent variable or strictly as an independent variable predicting policy.

\section{Unique Contributions of this Issue}

The 11 articles included in this Special Issue each make a unique contribution to the advancement of the field of attitudes toward redistributive policies. They examine the effects of both objective and subjective material interests or economic position, values orientations, and social stratification via ethnicity, race, and immigration status. Most studies are cross-national, drawing on the International Social Survey Programme (ISSP) or European Social Survey (ESS) data, but two focus on Germany and one focuses on neighborhood differences within a single city, New York.

\subsection{Interests, Macroeconomics, and Positions in the Socioeconomic Structure}

In their article, Evans and Kelley [91] seek to explain a key paradox in studies of social policy preferences-relatively low levels of support for the welfare state within the Nordic countries, the most generous welfare states. Through an analysis of public perceptions of inequality and redistributive preferences from the ISSP at the individual level and a scale of "welfarism" at the country level, they provide evidence that support for redistribution bears little overall relationship to welfare state activity except among the wealthy, who are less supportive in more generous welfare states. The authors contend that this represents a form of upper class "fatigue" from decades of egalitarian policies and paying high taxes. Their findings mostly contradict materialist explanations of attitudes, because attitudes do not follow purely from the ownership of the means of production. Instead, there is evidence that attitudes follow institutions and framing where states have longstanding normative effects on their publics; these publics are more likely to support the redistributive social policy status quo than to respond to their own impressions of the level of inequality in society. At the same time, their results are layered, and they find evidence of individual self-interest and group-interests derived from affinity to reference groups: The poor support redistribution regardless of tax increases that would harm them, while the rich are opposed to increased tax burdens in general. They term the complexities of these interests as the "me-and-mine" hypothesis. They follow up their cross-national evidence with a survey in the United States that helps to reduce the causal uncertainty in their arguments; by asking individuals to report how they think a change in inequality would affect their position, Evans and Kelley specifically target their perceived material interests.

Fatke [92] offers additional insight into how perceptions of the actual level of inequality in a country are related to preferences for policies that address such inequalities. He examines how relative-rather than absolute-position in a society is related to preferences for redistribution through analyzing three waves of ISSP data (1992, 1999, and 2009). He demonstrates that inequality perceptions are most strongly associated with greater support for redistribution among those who perceive themselves to be at the top of the social ladder. Thus, he contributes in general to an understanding of the role of subjectivity in preferences but also offers specific findings about the preferences of the upper class like Evans and Kelley [91] — a topic under-researched in the literature.

Naumann's [93] article offers one approach to examining Evans and Kelley's [91] proposal about tax fatigue. Using data from a series of survey experiments in the German Internet Panel (GIP), Naumann explores whether support for the welfare state is lower after people are made aware of its costs. He demonstrates that tax constraints (reminders that a given social policy may lead to higher taxes) are associated with lower support for unemployment benefits and for redistribution, but do not affect support for more spending on pensions, healthcare, or long-term care. He finds surprisingly little evidence that responses to tax constraints varied by political ideology. However, he did find some variation by class. In particular, Naumann's results demonstrate that low-income respondents are less responsive to the risk of tax burdens and maintain their high support for redistribution and the welfare state regardless, consistent with Evans and Kelley's findings. His general conclusion that 
attitudes towards the welfare state are not independent of attitudes towards taxation has important implications for future studies of social policy preferences. He contends that studies of taxation and welfare state attitudes should be combined.

Taking on preferences among the group at the other end of the socioeconomic spectrum, Levanon [94] endeavors to understand how social policy shapes the policy preferences of the working poor. Using cross-national data from both the ISSP and the ESS, including 31 countries at 13 different time-points between 1985 and 2010, he demonstrates that the degree of support for redistribution among the working poor is notably closer to the average degree reported by nonworking poor individuals than the mean level reported by nonpoor workers. From this, Levanon suggests that income is more important in shaping policy preferences than employment status. However, he also finds that in countries providing a greater degree of employment protection, the preference gap between nonpoor workers and the working poor is smaller, and overall support for redistribution is greater. He attributes this distinction to the importance of employment security as a major policy instrument shaping perceptions of policy and employment prospects. This also highlights the role of context in shaping redistributive preferences.

Also interested in the consequences of labor market conditions, Hess [95] analyzes the effects of changes in retirement policy intended to prolong working life in Germany. He uses data from the German Socio-Economic Panel Study (GSOEP) and the German Aging Survey (DEAS) and finds that these policy changes yield key differences in expectations about retirement by class. In particular, while high-skilled workers both want and expect to retire late, low-skilled workers prefer to retire early but expect that they have to work longer in order to ensure a reasonable pension. Hess concludes that such diverging expectations portend rising social inequality in the transition from work to retirement in Germany.

\subsection{Socialization Effects}

This issue also includes three key contributions to a little-understood area of policy preference formation-how earlier experiences in life shape adult preferences. Mijs [96] theorizes that socializing institutions such as schools and neighborhoods are "inferential spaces" that shape how children and young adults come to learn about an unequal society and their places in it. He suggests that a better understanding of such origins of inequality beliefs will allow scholars to determine which experiences and environments most powerfully influence the development of policy preferences.

Van Heuvelen and Copas's [97] examination of differences across birth cohorts' preferences for redistribution over time adds empirical weight to Mijs's [96] theories. They combine 21 waves of cross-national survey data using the ISSP and ESS data covering 54 countries, 32 years, and over a century of birth years. They find a great deal of variation in the effects of intercohort dynamics on the nature of change in support for redistribution, arguing that such changes result from socialization into different cultural zeitgeists. On the other hand, they find that support does not cluster well by welfare regime type. For example, they repeatedly find greater change in support for redistribution across cohorts and across years within countries than across welfare-state regimes. Their finding about plummeting support among younger cohorts in Nordic countries suggests that rich person tax "fatigue" may not be the only factor in waning redistributive policy support.

With additional evidence about the power of socialization, Ignácz [98] finds notable cross-country differences between Western and post-socialist societies in individuals' attitudes toward income inequality, even three decades after the end of the Cold War. Applying an adapted age-period-cohort analysis on the dataset of the 1992, 1999, and 2009 waves of the ISSP's Social Inequality module, Ignácz demonstrates that socialization has a substantial effect on attitudes and that socialist socialization clearly differentiates individuals from post-socialist countries from those from the West. Her results underline that experiences gained in formative years are crucial for attitudes and that both perceptions of and preferences for income inequality are influenced by socialization. 


\subsection{Immigration and Diversity}

Finally, several of our authors take on social stratification with studies of the timely topic of the roles of immigration and racial and ethnic diversity in shaping social policy preferences. Heizmann, Jeidinger, and Perry [99] examine the welfare chauvinism hypothesis, the idea that immigrants should not have the same access to welfare resources as natives. They examine how both objective and subjective material deprivation are related to welfare chauvinism using two waves of the ESS data (2008 and 2016) from 26 countries. Consistent with Fatke's [92] findings above, they find that perceptions of deprivation are more meaningful than objective factors regarding potential job loss in predicting attitudes. However, at the country level, they find that higher levels of asylum seeking are related to lower levels of welfare chauvinism. In this case, theories of deservingness, if asylum seekers are understood to be a "deserving" group, triumph over the welfare chauvinism hypothesis.

In another re-examination of competitive threat theory, Kwak and Wallace [100] investigate the impact of the Great Recession on perceived immigrant threat. Using data from the 2013 ISSP module on National Identity, they analyze individual-level data nested within 22 countries. They find that the Great Recession is positively associated with perceived immigrant threat and that these effects interact with change in government expenditures at the country level, and with age, educational levels, citizenship, and urban residence at the individual level. Kwak and Wallace's results add to a growing literature on the relationship between immigrant threat and economic inequality. Their findings about lower threat in urban contexts are also consistent with the theory proposed by Steele and Perkins about intergroup contact in more diverse settings.

Consistent with Heizmann, Jeidinger, and Perry's [99] findings, Steele and Perkins [101] challenge the idea that ethnic heterogeneity universally decreases support for the welfare state through an empirical focus on neighborhood-level dynamics. Using original survey data from a pilot study of 320 New York City residents, the authors focus on perception. While Fatke [92] and Heizmann, Jeidinger, and Perry [99] above focused on perceptions of individual SES, Steele and Perkins examine how perceptions of the ethnic/racial composition of respondents' neighborhoods of residence affect support for redistribution and social policies among majority and minority group members. Their focus on NYC, unusual for its long history of immigration and ethnic and racial diversity, allows them to offer a contrast with findings from countries that are experiencing recent surges in racial/ethnic or immigrant diversity. The authors find few differences in support for redistribution and social policies among white respondents perceiving themselves to be in more versus less heterogeneous neighborhoods, although black respondents who perceive themselves to live in whiter neighborhoods were less supportive.

\section{Summary}

Among the key contributions of this Special Issue to the existing research on redistribution and social policy preferences are novel explorations of how socialization affects preferences for redistribution; an examination of how perceptions about inequality translate into policy preferences; a call for more research into the links between taxation and social policy preferences; explanations for the paradox of low levels of support for redistribution in the famously-generous Nordic countries; and new insights into class-specific policy preferences as well as the roles of immigration and diversity in determining such preferences.

Funding: This research received no external funding.

Conflicts of Interest: The authors declare no conflict of interest.

\section{References}

1. Piketty, T.; Saez, E. Inequality in the long run. Science 2014, 344, 838-843. [CrossRef] [PubMed]

2. Hacker, J.S. Privatizing Risk without Privatizing the Welfare State: The Hidden Politics of Social Policy Retrenchment in the United States. Am. Political Sci. Rev. 2004, 98, 243-260. [CrossRef] 
3. Pierson, P. Dismantling the Welfare State? Reagan, Thatcher and the Politics of Retrenchment; Cambridge University Press: Cambridge, UK, 1994; ISBN 0521403820.

4. Huber, E.; Stephens, J.D. Income inequality and redistribution in post-industrial democracies: Demographic, economic and political determinants. Socio-Econ. Rev. 2014, 12, 245-267. [CrossRef]

5. Palme, J. Welfare states and inequality: Institutional designs and distributive outcome. Res. Soc. Stratif. Mobil. 2006, 24, 387-403. [CrossRef]

6. Pickett, K.; Wilkinson, R. Income Inequality and Health: A Causal Review. Soc. Sci. Med. 2015, 128, 316-326. [CrossRef] [PubMed]

7. Chamlin, M.B.; Cochran, J.K. Ascribed Economic Inequality and Homicide Among Modern Societies. Homicide Stud. 2005, 9, 3-29. [CrossRef]

8. Wilkinson, R.; Pickett, K. Income Inequality and Social Dysfunction. Annu. Rev. Sociol. 2009, 35, 493-511. [CrossRef]

9. Piketty, T. Capital in the Twenty-First Century; Translatio.; Harvard University Press: Cambridge, UK, 2014.

10. Eger, M.A.; Valdez, S. Neo-nationalism in Western Europe. Eur. Sociol. Rev. 2015, 31, 115-130. [CrossRef]

11. Pierson, P. American hybrid: Donald Trump and the strange merger of populism and plutocracy. Br. J. Sociol. 2017, 68, S105-S119.

12. Scruggs, L.; Hayes, T.J. The Influence of Inequality on Welfare Generosity. Political Soc. 2017, 45, 35-66. [CrossRef]

13. Jerrim, J.; Macmillan, L. Income Inequality, Intergenerational Mobility, and the Great Gatsby Curve: Is Education the Key? Soc. Forces 2015, 94, 505-533. [CrossRef]

14. Coughlin, R. Ideology, Public Opinion and Welfare Policy: Attitudes toward Taxes and Spending in Industrialized Societies; University of California Press: Berkeley, CA, USA, 1980.

15. Eagly, A.H.; Chaiken, S. The Psychology of Attitudes; Harcourt Brace: Fort Worth, TX, USA, 1993.

16. Crano, W.D.; Cooper, J.; Forgas, J.P. Attitudes and Attitude Change: An Introductory Review. In The Psychology of Attitudes and Attitude Change; Forgas, J.P., Cooper, J., Crano, W.D., Eds.; The Sydney Symposium of Social Psychology Series; Psychology Press: New York, NY, USA, 2010; pp. 3-17. ISBN 9780203841303.

17. Ajzen, I.; Fishbein, M. Attitudes and the Attitude-Behavior Relation: Reasoned and Automatic Processes. Eur. Rev. Soc. Psychol. 2000, 11, 1-33. [CrossRef]

18. Perloff, R.M. The Dynamics of Persuasion: Communication and Attitudes in the 21st Century; Routledge: New York, NY, USA, 1993; ISBN 1135639264.

19. Gilens, M. Inequality and Democratic Responsiveness. Public Opin. Q. 2005, 69, 778-796. [CrossRef]

20. Wlezien, C. Patterns of Representation: Dynamics of Public Preferences and Policy. J. Political 2004, 66, 1-24. [CrossRef]

21. DiMaggio, P.; Louch, H. Socially embedded consumer transactions: For what kinds of purchases do people most often use networks? Am. Sociol. Rev. 1998, 63, 619-637. [CrossRef]

22. Brooks, C.; Manza, J. Social Policy Responsiveness in Developed Democracies. Am. Sociol. Rev. 2006, 71, 474-494. [CrossRef]

23. Schulze-Cleven, T.; Weishaupt, J.T. Playing Normative Legacies: Partisanship and Employment Policies in Crisis-Ridden Europe. Political Soc. 2015, 43, 269-299. [CrossRef]

24. Feldman, S. Structure and Consistency in Public Opinion: The Role of Core Beliefs and Values. Am. J. Political Sci. 1988, 32, 416-440. [CrossRef]

25. Taylor-Gooby, P. Legitimation Deficit, Public Opinion and the Welfare State. Sociology 1983, 17, $165-184$. [CrossRef]

26. Linos, K.; West, M. Self-interest, Social Beliefs, and Attitudes to Redistribution. Re-addressing the Issue of Cross-national Variation. Eur. Sociol. Rev. 2003, 19, 393-409. [CrossRef]

27. Weakliem, D. Class-Consciousness and Political-Change-Voting and Political-Attitudes in the British Working-Class, 1964 to 1970. Am. Sociol. Rev. 1993, 58, 382-397. [CrossRef]

28. Splichal, S. Public Opinion: Developments and Controversies in the Twentieth Century; Rowman \& Littlefield Publishers: Oxford, UK, 1999.

29. Habermas, J. The Structural Transformation of the Public Sphere: An Inquiry into a Category of Bourgeois Society; Burger, T., Lawrence, F., Eds.; English Tr.; MIT Press: Cambridge, UK, 1989.

30. Allport, F.H. Toward a Science of Public Opinion. Public Opin. Q. 1937, 1, 7-23. [CrossRef] 
31. Soroka, S.N.; Wlezien, C. Degrees of Democracy: Politics, Public Opinion and Policy; Cambridge University Press: Cambridge, UK, 2010.

32. Burstein, P. The Impact of Public Opinion on Public Policy: A Review and an Agenda. Political Res. Q. 2003, 56, 29-40. [CrossRef]

33. Key, V.O. Public Opinion and American Democracy; Knopf: New York, NY, USA, 1961.

34. Breznau, N. Anti-immigrant Parties and Western European Society: Analyzing the Role of Immigration and Forecasting Voting. 2018. Available online: https://osf.io/8hyrx/ (accessed on 27 June 2019).

35. Taylor-Gooby, P. Sustaining State Welfare in Hard Times: Who will Foot the Bill? J. Eur. Soc. Policy 2001, 11, 133-147. [CrossRef]

36. Howard, C. The Hidden Welfare State: Tax Expenditures and Social Policy in the United States; Princeton University Press: Princeton, NJ, USA, 1997.

37. Downs, A. An Economic Theory of Democracy; Harper and Row: New York, NY, USA, 1957.

38. Calvert, R.L. Robustness of the Multidimensional Voting Model: Candidate Motivations, Uncertainty, and Convergence. Am. J. Political Sci. 1985, 29, 69-95. [CrossRef]

39. Wittman, D.A. Parties as Utility Maximizers. Am. Political Sci. Rev. 1973, 67, 490-498. [CrossRef]

40. Kroneberg, C.; Kalter, F. Rational Choice Theory and Empirical Research: Methodological and Theoretical Contributions in Europe. Annu. Rev. Sociol. 2012, 38, 73-92. [CrossRef]

41. Boudon, R. What middle range theories are. Contemp. Sociol. 1991, 20, 519-522. [CrossRef]

42. Kalberg, S. Max Weber's Types of Rationality: Cornerstones for the Analysis of Rationalization Processes in History. Am. J. Sociol. 1980, 85, 1145-1179. [CrossRef]

43. Schmidt-Catran, A.W. Economic Inequality and Public Demand for Redistribution: Combining Cross-Sectional and Longitudinal Evidence. Socio-Econ. Rev. 2016, 14, 119-140. [CrossRef]

44. Kevins, A.; Horn, A.; Jensen, C.; van Kersbergen, K. Yardsticks of inequality: Preferences for redistribution in advanced democracies. J. Eur. Soc. Policy 2018, 28, 402-418. [CrossRef]

45. Branko, M. The median-voter hypothesis, income inequality, and income redistribution: An empirical test with the required data. Eur. J. Political Econ. 2000, 16, 367-410.

46. Breznau, N.; Eger, M.A. Immigrant Presence, Group Boundaries, and Support for the Welfare State in Western European Societies. Acta Sociol. 2016, 59, 195-214. [CrossRef]

47. Gingrich, J.; Ansell, B. Preferences in Context: Micro Preferences, Macro Contexts, and the Demand for Social Policy. Comp. Political Stud. 2012, 45, 1624-1654. [CrossRef]

48. Alt, J.; Iversen, T. Inequality, Labor Market Segmentation, and Preferences for Redistribution. Am. J. Political Sci. 2017, 61, 21-36. [CrossRef]

49. Iversen, T.; Soskice, D. An Asset Theory of Social Policy Preferences. Am. Political Sci. Rev. 2001, 95, 875-893. [CrossRef]

50. McLaren, L.M. Anti-immigrant prejudice in Europe: Contact, threat perception, and preferences for the exclusion of migrants. Soc. Forces 2003, 81, 909-936. [CrossRef]

51. Mewes, J.; Mau, S. Globalization, Socio-economic Status and Welfare Chauvinism: European perspectives on Attitudes toward the Exclusion of Immigrants. Int. J. Comp. Sociol. 2013, 54. [CrossRef]

52. Schmidt-Catran, A.W.; Spies, D.C. Immigration and Welfare Support in Germany. Am. Sociol. Rev. 2016, 81, 242-261. [CrossRef]

53. Eger, M.A. Even in Sweden: The Effect of Immigration on Support for Welfare State Spending. Eur. Sociol. Rev. 2010, 26, 203-217. [CrossRef]

54. Eger, M.A.; Breznau, N. Immigration and the Welfare State: A Cross-Regional Analysis of European Welfare Attitudes. Int. J. Comp. Sociol. 2017, 58, 440-463. [CrossRef]

55. Breznau, N. Economic Equality and Social Welfare: Policy Preferences in Five Nations. Int. J. Public Opin. Res. 2010, 22, 458-484. [CrossRef]

56. Lewis, J. Constructing Public Opinion: How Political Elites Do What They Like and Why We Seem to Go Along with It; Colubmia University Press: New York, NY, USA, 2001.

57. Mondak, J.J. Public opinion and heuristic processing of source cues. Political Behav. 1993, 15, 167-192. [CrossRef]

58. Mullinix, K.J. Partisanship and Preference Formation: Competing Motivations, Elite Polarization, and Issue Importance. Political Behav. 2016, 38, 383-411. [CrossRef] 
59. Judd, C.M.; Krosnick, J.A. The Structural Bases of Consistency among Political Attitudes: Effects of Political Expertise and Attitude Importance. In Attitude Structure and Function; Pratkanis, A.R., Breckler, S.J., Greenwald, A.G., Eds.; Psychology Press Taylor \& Francis Group: New York, NY, USA; London, UK, 1989; pp. 99-128.

60. Krosnick, J.A.; Boninger, D.S.; Chuang, Y.C.; Berent, M.K.; Carnot, C.G. Attitude strength: One construct or many related constructs? J. Pers. Soc. Psychol. 1993, 65, 1132. [CrossRef]

61. Barnes, L.; Hicks, T. Making Austerity Popular: The Media and Mass Attitudes toward Fiscal Policy. Am. J. Political Sci. 2018, 62, 340-354. [CrossRef]

62. Hasenfeld, Y.; Rafferty, J.A. The Determinants of Public Attitudes toward the Welfare State. Soc. Forces 1989, 67, 1027-1048. [CrossRef]

63. Arts, W.; Gijsberts, M. After the Velvet Revolutions: Altered Life-Chances, Fragile Legitimacy, and Split Consciousness in Post-Communist Eastern Europe. Soc. Justice Res. 1998, 11, 143-171. [CrossRef]

64. Wegener, B.; Liebig, S. Is the "Inner Wall" Here to Stay? Justice Ideologies in Unified Germany. Soc. Justice Res. 2000, 13, 177-197. [CrossRef]

65. Shapiro, R.Y.; Young, J.T. Public Opinion and the Welfare State: The United States in Comparative Perspective. Political Sci. Q. 1989, 104, 59-89. [CrossRef]

66. Rudolph, T.J.; Evans, J. Political Trust, Ideology, and Public Support for Government Spending. Am. J. Political Sci. 2005, 49, 660-671. [CrossRef]

67. Rudolph, T.J. Political Trust, Ideology, and Public Support for Tax Cuts. Public Opin. Q. 2009, 73, $144-158$. [CrossRef]

68. Bain, R. An Attitude on Attitude Research. Am. J. Sociol. 1928, 33, 940-957. [CrossRef]

69. Groves, R.M.; Lyberg, L. Total Survey Error: Past, Present, and Future. Public Opin. Q. 2010, 74, 849-879. [CrossRef]

70. Perrin, A.J.; McFarland, K. Social Theory and Public Opinion. Annu. Rev. Sociol. 2011, 37, 87-107. [CrossRef]

71. Ansolabehere, S.; Rodden, J.; Snyder, J.M., Jr. The Strength of Issues: Using Multiple Measures to Gauge Preference Stability, Ideological Constraint, and Issue Voting. Am. Political Sci. Rev. 2008, 102, $215-232$. [CrossRef]

72. Achen, C.H. Mass Political Attitudes and the Survey Response. Am. Political Sci. Rev. 1975, 69, $1218-1231$. [CrossRef]

73. Andrews, F.M. Construct Validity and Error Components of Survey Measures: A Structural Modeling Approach. Public Opin. Q. 1984, 48, 409-442. [CrossRef]

74. Diamantopoulos, A.; Sarstedt, M.; Fuchs, C.; Wilczynski, P.; Kaiser, S. Guidelines for choosing between multi-item and single-item scales for construct measurement: A predictive validity perspective. J. Acad. Mark. Sci. 2012, 40, 434-449. [CrossRef]

75. Evans, M.D.R.; Kelley, J. Trends in Women's Labor Force Participation in Australia: 1984-2002. Soc. Sci. Res. 2008, 37, 287-310. [CrossRef]

76. Warshaw, C. Latent Constructs in Public Opinion. In the Oxford Handbook of Polling and Survey Methods; Atkeson, L.R., Alvarez, R.M., Eds.; Oxford University Press, Oxford Handbooks Online: Oxford, UK, 2017; Volume 1, pp. 1-29.

77. Roosma, F.; Gelissen, J.; van Oorschot, W. The Multidimensionality of Welfare State Attitudes: A European Cross-National Study. Soc. Indic. Res. 2013, 113, 235-255. [CrossRef] [PubMed]

78. van Oorschot, W.; Meuleman, B. Welfarism and the Multidimensionality of Welfare State Legitimacy: Evidence from The Netherlands, 2006. Int. J. Soc. Welf. 2012, 21, 79-93. [CrossRef]

79. Wlezien, C. The Public as Thermostat: Dynamics of Preferences for Spending. Am. J. Political Sci. 1995, 39, 981-1000. [CrossRef]

80. Jæger, M.M. Welfare Regimes and Attitudes Towards Redistribution: The Regime Hypothesis Revisited. Eur. Sociol. Rev. 2006, 22, 157-170. [CrossRef]

81. Steele, L.G. Income Inequality, Equal Opportunity, and Attitudes About Redistribution. Soc. Sci. Q. 2015, 96, 444-464. [CrossRef]

82. Svallfors, S. Worlds of Welfare and Attitudes to Redistribution: A Comparison of Eight Western Nations. Eur. Sociol. Rev. 1997, 13, 283-304. [CrossRef]

83. Lupu, N.; Pontusson, J. The Structure of Inequality and the Politics of Redistribution. Am. Political Sci. Rev. 2011, 105, 316-336. [CrossRef] 
84. Bowles, S. Endogenous Preferences: The Cultural Consequences of Markets and Other Economic Institutions. J. Econ. Lit. 1998, 36, 75-111.

85. Dobbins, M.; Busemeyer, M.R. Socio-economic institutions, organized interests and partisan politics: The development of vocational education in Denmark and Sweden. Socio-Econ. Rev. 2015, 13, 259-284. [CrossRef]

86. Marx, P. The effect of job insecurity and employability on preferences for redistribution in Western Europe. J. Eur. Soc. Policy 2014, 24, 351-366. [CrossRef]

87. Pierson, P. When Effect Becomes Cause: Policy Feedback and Political Change. World Political 1993, 45, 595-628. [CrossRef]

88. Breznau, N. Positive Returns and Equilibrium: Simultaneous Feedback Between Public Opinion and Social Policy. Policy Stud. J. 2017, 45, 583-612. [CrossRef]

89. Breznau, N. Simultaneous Feedback Models with Macro-Comparative Cross-sectional Data. Methods Data Anal. 2018, 12, 265-308.

90. Jennings, W. The Public Thermostat, Political Responsiveness and Error-Correction: Border Control and Asylum in Britain, 1994-2007. Br. J. Political Sci. 2009, 39, 847-870. [CrossRef]

91. Evans, M.D.R.; Kelley, J. Strong Welfare States Do Not Intensify Public Support for Income Redistribution, but Even Reduce It among the Prosperous: A Multilevel Analysis of Public Opinion in 30 Countries. Societies 2018, 8, 105. [CrossRef]

92. Fatke, M. Inequality Perceptions, Preferences Conducive to Redistribution, and the Conditioning Role of Social Position. Societies 2018, 8, 99. [CrossRef]

93. Naumann, E. Tax Constraints, Social Policy Preferences, and Support for Redistribution. Societies 2018, 8, 46. [CrossRef]

94. Levanon, A. Labor Market Insiders or Outsiders? A Cross-National Examination of Redistributive Preferences of the Working Poor. Societies 2018, 8, 72. [CrossRef]

95. Hess, M. Retirement Expectations in Germany-Towards Rising Social Inequality? Societies 2018, 8, 50. [CrossRef]

96. Mijs, J.J.B. Inequality Is a Problem of Inference: How People Solve the Social Puzzle of Unequal Outcomes. Societies 2018, 8, 64. [CrossRef]

97. VanHeuvelen, T.; Copas, K. The Intercohort Dynamics of Support for Redistribution in 54 Countries, 1985-2017. Societies 2018, 8, 69. [CrossRef]

98. Ignácz, Z.S. The Remains of the Socialist Legacy: The Influence of Socialist Socialization on Attitudes toward Income Inequality. Societies 2018, 8, 62. [CrossRef]

99. Heizmann, B.; Jedinger, A.; Perry, A.; Heizmann, B.; Jedinger, A.; Perry, A. Welfare Chauvinism, Economic Insecurity and the Asylum Seeker "Crisis". Societies 2018, 8, 83. [CrossRef]

100. Kwak, J.; Wallace, M. The Impact of the Great Recession on Perceived Immigrant Threat: A Cross-National Study of 22 Countries. Societies 2018, 8, 52. [CrossRef]

101. Steele, L.; Perkins, K. The Effects of Perceived Neighborhood Diversity on Preferences for Redistribution: A Pilot Study. Societies 2018, 8, 82. [CrossRef]

(C) 2019 by the authors. Licensee MDPI, Basel, Switzerland. This article is an open access article distributed under the terms and conditions of the Creative Commons Attribution (CC BY) license (http://creativecommons.org/licenses/by/4.0/). 